tinues to carry a greater risk of psychiatric disturbance. It cannot be assumed from present evidence that the findings of this study are a consequence of current practice in haemophilia care, although it may well be so. Only after further investigation will it be possible to determine clinical policies and deploy resources on the basis of accurate information about children's needs.

This study was supported by the Yorkhill Leukaemia and Cancer Research Fund. We thank Dr A Pettigrew and Sister C Murphy of the haemophilia clinic and Dr J M Richardson and Sister M Maclean of the diabetic clinic. General practitioners in Glasgow, Kirkintilloch, Bearsden, Alexandria, and Isle of Bute generously helped in recruiting control subjects. Professor F H Stone and Dr V Kusumaker were instrumental in setting up the project.

1 Haggerty RJ. Preface. In: Pless IB, Pinkerton P, eds. Chronic childhood disorder-promoting patterns of adjustment. London: Henry Kimpton, 1975:11.

2 Rae-Grant Q. Psychological problems in the medically ill child. Pediatr Clin North Am 1985;8:653-63.

3 Rutter M, Tizard J, Whitmore K. Education, health and behaviour. London Longman, 1970.

4 Leslie SA. Psychiatric disorder in the adolescents of a new town. $\mathrm{Br} \mathcal{J}$ Psychiatry 1974;125:113-24.

5 Pless IB, Roghman KJ. Chronic illness and its consequences: observation based on three epidemiologic surveys. I Pediatr 1971;79:351-9.

6 Mattson A, Gross S. Adaptational and defensive behaviour in young haemophiliacs and their parents. Am f Psychiatry 1966;122:1349-56.

7 Bronks IG, Blackburn EK. A socio-medical study of haemophilia and related sronks IG, Blackburn EK. A socio-medical study of haemophilia and re
states. British fournal of Preventive and Social Medicine 1968;22:68-72.

states. Britsh fournal of Preventive and Social Medicine 1968;22:68-72.
Spencer RF. Incidence of social and psychiatric problems in a group of haemophiliac patients. N C Med f 1968;29:332-5.

Boon RA, Roberts DF. The social impact of haemophilia. 7 Biosoc $S c i$ 1970;2:237-64.
.

10 Markova I, Lockyer R, Forbes CD. Haemophilia: a survey on social issues. Health Bull (Edinb) 1977;35:177-82.

11 Meijer A. Psychiatric problems of haemophilic boys and their families. Int $\mathcal{P}$ Psychiatry Med 1980;10:163-72.

12 Maclean A. The haemophiliac in school: issues of adjustment and communication [Dissertation]. Glasgow: University of Glasgow, 1985:17-27.

13 Steinhausen H-C. Chronically ill and handicapped children and adolescents: personality studies in relation to disease. F Abnorm Child Psychology 1981;9:291-7.

14 Richman N, Stevenson J, Graham PJ. Pre-school to school: a behavioural study. London: Academic Press, 1982.

15 Kovacs M. The children's depression inventory. Psychopharmacol Bull 1985;21:995-8.

16 Kovacs M, Brent D, Steinberg TF, Paulauskas S, Reid J. Children's selfreports of psychologic adjustment and coping strategies during first year of insulin-dependent diabetes mellitus. Diabetes Care 1986;9:472-9.

17 Knight D, Hensley VR, Waters B. Validation of the children's depression scale and the children's depression inventory in a prepubertal sample. $f$ Child Psychol Psychiatry 1988;29:853-63.

18 Smucker MR, Craighead WE, Craighead LW, Green BJ. Normative and reiiability data for the children's depression inventory. I Abnorm Child Psychol 1986;14:25-39.

19 Gore SM, Altman DG. Statistics in practice. London: BMA, 1989.

(Accepted 19 September 1990)

\title{
Increased energy expenditure in Parkinson's disease
}

\author{
Samuel Levi, Malcolm Cox, Myriam Lugon, \\ Malcolm Hodkinson, Andrew Tomkins
}

Department of Geriatric

Medicine, University

College and Middlesex

Hospital School of

Medicine, St Pancras

Hospital, London

NW1 2PE

Samuel Levi, MB, registrar

Myriam Lugon, MRCP, senior registrar

Malcolm Hodkinson, FRCP, professor

\section{Clinical Nutrition Unit,}

Department of Clinical

Sciences, London School

of Hygiene and Tropical

Medicine, London

WC1E 7HT

Malcolm Cox, MSC, scientist

Andrew Tomkins, FRCP,

senior lecturer

Correspondence to:

Professor A Tomkins,

Department of International

Child Health, Institute of

Child Health, Guilford

Street, London

WCIN 1EH.

Br.Med F 1990;301:1256-7
We have noted that patients with Parkinson's disease tend to be thin compared with other subjects but, apart from a recent report, this observation is not recorded in the literature. ${ }^{1}$ Weight loss is to be expected if there is a discrepancy between dietary intake and energy expenditure. In view of the considerable changes in muscular tone and involuntary movements that are characteristic of patients with Parkinson's disease we investigated energy expenditure in patients before and after treatment for their disease.

\section{Patients, methods, and results}

Fourteen patients with Parkinson's disease were studied ( 9 women and 5 men, mean age 70.4 (SE 5.8) years). Sixteen healthy elderly volunteers (il women and 5 men, mean age $76.5(9.0)$ years) were also studied. The protocol was approved by the ethical committee of the school of medicine.

Patients with Parkinson's disease weighed less than healthy subjects $(60.9(10.8) \mathrm{kg} v 66.8(12.6) \mathrm{kg})$. Patients with Parkinson's disease also had less lean body mass, calculated from skinfold measurements $(46.6(7 \cdot 6) \mathrm{kg} v 50 \cdot 2(11 \cdot 2) \mathrm{kg}),{ }^{2}$ but these differences were not statistically significant.

Resting energy expenditure was measured by indirect calorimetry using a ventilated hood technique in which a transparent acrylic hood is placed over the subject's head and shoulders and expired air is sucked from the hood continuously; the concentrations of
Energy expenditure (mean $(S D) \mathrm{kF} / \mathrm{kg}$ body weight $/ 24 \mathrm{~h}$ ) before and after drug treatment for Parkinson's disease

\begin{tabular}{lcccc}
\hline & $\begin{array}{c}\text { Patients with no } \\
\text { clinical change } \\
(\mathrm{n}=8)\end{array}$ & $\begin{array}{c}\text { Patients with } \\
\text { reduction of } \\
\text { hypertonia }(\mathrm{n}=3)\end{array}$ & $\begin{array}{c}\text { Patients with } \\
\text { increased voluntary } \\
\text { movements }(\mathrm{n}=3)\end{array}$ & Controls $(\mathrm{n}=16)$ \\
\hline $\begin{array}{l}\text { Before treatment } \\
\text { After treatment }\end{array}$ & $94 \cdot 5(14 \cdot 6)$ & $116 \cdot 2(19 \cdot 6)$ & $\left.\begin{array}{c}92 \cdot 0(14 \cdot 6) \\
115 \cdot 8(36 \cdot 8)\end{array}\right\} 81 \cdot 1(8 \cdot 4)$ \\
\hline
\end{tabular}

oxygen and carbon dioxide were measured with equipment described elsewhere. ${ }^{3}$ Values for resting energy expenditure were obtained from standard equations using the concentrations of carbon dioxide and oxygen in expired air at a time when the levels had reached steady state for at least 10 minutes. In practice, this was after 20-30 minutes of wearing the hood.

Measurements were made in the morning, the patient not having taken food or their drugs for Parkinson's disease since the previous evening, though drinks of water were allowed. Patients then took their normal dose of drug and a second measurement was made once the "new" level of neuromuscular tone and involuntary movements had become established. In practice, this was within 60 minutes of the initial measurement.

The response to the drug was variable. In eight patients there was negligible change; involuntary movements did not occur and changes in muscle tone were minimal. The remaining six patients showed striking clinical changes. Three had appreciable hypertonia during the first measurement and showed a reduction in muscle tone after swallowing their tablets. A further three were mildly hypertonic before treatment and developed striking involuntary movements shortly after swallowing their tablets. The table compares the results in these three groups with those in controls.

Overall, the resting energy expenditure in patients with Parkinson's disease was significantly $(p<0.005)$ higher than in healthy subjects whether the data were expressed as mean (SD) $\mathrm{kJ} / \mathrm{kg}$ body weight $/ 24 \mathrm{~h}(98 \cdot 6$ $(17 \cdot 1) v 81 \cdot 1(8 \cdot 4))$ or as $\mathrm{kJ} / \mathrm{kg}$ lean body mass $/ 24 \mathrm{~h}$ $(128 \cdot 3(17 \cdot 1) v 109 \cdot 5(11 \cdot 7))$. There was little change in resting energy expenditure after drug treatment in eight patients with no clinical change, but patients in whom a hypertonic state was caused by drugs showed a reduction in resting energy expenditure and those in whom involuntary movements were released by drugs showed an increase.

\section{Comment}

The importance of maintaining adequate nutritional state of the elderly, especially during illness, is increasingly recognised. ${ }^{4}$ In many elderly subjects the main reason for malnutrition is a reduction in dietary intake for a variety of biological, social, and cultural reasons. Our data suggest that some patients with Parkinson's 
disease may have greatly increased energy requirements because of their abnormal neuromuscular state. The findings presented here show that energy expenditure can vary at different stages of the day. Nevertheless, it seems that increased energy requirements may be an important contributor to the clinical syndrome of thinness in Parkinson's disease and we suggest that this should be considered in the nutritional management of such patients.

We are grateful for a research fellowship from the Parkinson's Disease Society.
I Yapa RSS, Plavfer JR, Lve M. Anthropometric and nutritional assessment of elderly patients with Parkinson's disease. Fournal of Clinical and Experimental Gerontology 1989:11:155-64.

2 Durnin JVGA, Womersley J. Body fat assessed from body density and it estimation from skinfold thickness: measurements on 481 men and women rom 16-72 years. Brf Nutr 1974;32:77-97.

3 Buchdahl RM, Cox M, Fulleylove M, Tomkins AM, Warner T, Brueton $M$ Increased resting energy expenditure in cystic fibrosis. F Appl Physiol 1988;64:1810-6.

4 Department of Health and Social Security. Nutrition and health in old age. London: HMSO, 1979. (Report on health and social subjects No 16. 5 Schorah CJ, Morgan DB. Nutritional deficiencies in the elderly. Hospital Update 1985;11:353-60.

(Accepted 15 August 1990)

\section{Retinoblastoma in grandchildren of workers at Sellafield nuclear plant}

\section{J A Morris, Jane M Edwards, Jennifer Buckler}

Department of Pathology, Lancaster Moor Hospital, Lancaster LA1 3JR J A Morris, FRCPATH, consultant pathologist Jane M Edwards, MRCPATH, senior registrar

\section{The Surgery, Kendal LA9 4BD \\ Jennifer Buckler, MRCGP, general practitioner}

Correspondence to: Dr Morris.

BrMed F 1990;301:1257

Evidence indicates that exposure of workers to radiation at Sellafield nuclear reprocessing plant increases the risk of acute lymphoblastic leukaemia in the next generation.' This could be due to a germinal mutation occurring in the workers or to an increased rate of somatic mutation occurring in their children during intrauterine or early extrauterine life. ${ }^{2}$ One way to investigate this is to study the incidence of retinoblastoma in the offspring of those who work in the the genetic basis of retinoblastoma than of leukaemia and it is often possible to work out the stage at which mutation has occurred. For instance, if there is an increased rate of germinal mutation this would lead to an increased frequency of bilateral retinoblastoma, and nuclear industry. This is because more is known about an increased rate of somatic mutation would lead to an increased incidence of unilateral retinoblastoma.

We report three cases of retinoblastoma that are relevant to this debate. These cases were recognised not as a result of a systematic study but because the mother of the index child knew of the two other cases and brought them to our attention.

\section{Case reports}

The maternal grandfathers of all three children worked at Sellafield, and the mothers had lived in Seascale, a small village less than $3 \mathrm{~km}$ from Sellafield, during part of their childhood: one mother had been born there and the two others had moved there at the age of 6 months and 11 years of age. None of the children, however, had been born in Seascale. One child (case 1) developed a unilateral retinoblastoma at 6 months of age, which was treated by enucleation of the eye. At the age of 5 years she was well with no evidence of tumour in the remaining eye. The constitution of her chromosomes was $46, \mathrm{XX}$. The second child (case 2) developed a unilateral retinoblastoma at 12 months of age, which was treated by enucleation. The other eye was still free of tumour when she was seen at the age of 3 . The constitution of her chromosomes was $46, \mathrm{XX}$. The third child (case 3 ) developed retinoblastoma in one eye at 3 months of age, which was treated by enucleation, and a tumour in the other eye at 8 months, which was treated with a cobalt plaque. At the age of 12 she is well. The constitution of her chromosomes was $46, \mathrm{XX}$ with a partial deletion of one chromosome 13 (del 13 [q12-q21]); this defect was not present in the cells of either parent.

The diagnosis of retinoblastoma was confirmed by histological examination of the enucleated eyes in all three cases. There was no history of retinoblastoma in any other member of these families. In addition, the fundi of the parents of the three children showed no evidence of a healed retinoblastoma. The fathers of the children had not had any contact with the nuclear industry and had never worked in Cumbria.

\section{Comment}

There was no evidence of a germinal mutation derived from the maternal grandfather in any of the three cases. In case 3 there was evidence of a germinal mutation derived from one of the parents. In the two other cases the evidence pointed to somatic mutation, although the possibility of germinal mutation derived from the parents cannot be completely excluded.

It is, of course, possible that this cluster of cases is a chance occurrence unrelated to exposure to radiation. Retinoblastoma, however, is extremely rare, occurring with a frequency of 1 in 20000 live births and being 10 times less common than acute lymphoblastic leukaemia. To calculate the probability of a cluster of cases reliably it is necessary to define in advance the total population from which the cases have arisen. This is not possible if the cluster is observed in retrospect. In 1987, however, Gardner et al calculated that roughly 2600 children had been resident in Seascale at some time between 1950 and $1983 .^{+5}$ This cohort is unlikely to have produced more than 5000 children. The expected number of cases of retinoblastoma in 5000 children is 0.25 and the chance of three occurring is 0.002 .

If these cases are related to exposure to radiation then one possible explanation is that the mothers, who had spent part of their childhood in Seascale, had accumulated radionuclides and had an increased rate of cell mutation. This could then lead to an increased risk of a germinal mutation being passed on to the next generation and to an increased rate of somatic mutation affecting their children during intrauterine life. The mothers could have been exposed to radiation in the general environment or in contaminated homes. If this is the correct explanation it has important implications for the pathogenesis of other childhood tumours in this locality, and possible ways in which nuclear power workers contaminate their homes need urgent investigation. A large scale study of the incidence of retinoblastoma in the offspring of those who work in the nuclear industry is also required. This study will need to include not only the workers' children but also their children's children.

1 Gardner MJ, Snee MP, Hall AJ, Powell CA, Downes S, Terrell D. Results of a case-control study of leukaemia and lymphoma among young people near a case-control study of leukaemia and lymphoma among young people

2 Morris JA. Leukaemia and lymphoma among young people near Sellafield BrMed f 1990;300:676.

3 Goudie RB. What are antioncogenes? F Pathol 1988;154:297-8

4 Gardner MJ, Hall AJ, Downes S, Terrell JD. Follow up study of children born elsewhere but attending schools in Seascale, West Cumbria (schools cohort). Br.Med f 1987;295:819-22.

5 Gardner MJ, Hall AJ, Downes S, Terrell JD. Follow up study of childre born to mothers resident in Seascale, West Cumbria (birth cohort). Br Med $\mathcal{F}$ $1987 ; 295: 822-7$

(Accepted 10 fuly 1990) 